\title{
Consumer Acceptance of Mobile Marketing: An Empirical Study on the Saudi Female
}

\author{
Soad A. Al-Meshal ${ }^{1} \&$ Mohammad A. Almotairi ${ }^{1}$ \\ ${ }^{1}$ College of Business Administration, King Saud University, Riyadh, Saudi Arabia \\ Correspondence: Mohammad A. Almotairi, Chairman, Department of Marketing, College of Business \\ Administration, King Saud University, Riyadh, Saudi Arabia. E-mail: mohamed104@hotmail.com
}

Received: May 14, 2013

doi:10.5539/ijms.v5n5p94
Accepted: June 2, 2013 Online Published: September 16, 2013

URL: http://dx.doi.org/10.5539/ijms.v5n5p94

\begin{abstract}
This paper examines the factors that influence mobile marketing acceptance among female Saudi consumers. A survey was conducted using an electronic and self-administered questionnaire. A total of 300 questionnaires were distributed. The valid questionnaires were 226 ; thus the response rate is 0.75 . This study examines the following factors: providing information, content sharing, content access, personal attachment, and perceived value as independent factors. The mobile marketing acceptance was the dependent factor. Results of the study indicate there is a high association between study variables and mobile marketing acceptance. Conclusion, study limitation, and future studies were provided.
\end{abstract}

Keywords: mobile marketing acceptance, providing information, sharing content, accessing content, personal attachment, perceived value

\section{Introduction}

With significant growth in cell phone usage, technological developments have created new marketing communication channels. These digital channels have increased the possibilities to reach consumers by allowing personalization of the content and context.

The Mobile Marketing Association (MMA) defines mobile marketing as "the use of wireless media as an integrated content delivery and direct response vehicle within a cross media or standalone marketing communications program" (MMA, 2006). Specific consumer segments—such as the female market—are using mobile phones increasingly for multitasking (Gong \& Li, 2008; Plant, 2006; Sangwan \& Pau, 2005; Sultan et al., 2009).

Moreover, the advantages of mobile marketing are its ability to build and develop customer relationships. Furthermore, the majority of mobile devices are able to download applications, pictures, send and receive text, etc. Thus mobile marketing is used by marketers, consumers, mobile operators, and others to contact other points and receive a direct response.

Consumer engagements in mobile marketing efforts have attracted and challenged many researchers. Nevertheless, the extent to which consumers accept mobile marketing efforts remains unclear. Empirical studies on factors that influence mobile marketing acceptance are little in the Saudi context. Accordingly, the aim of this paper is to examine factors that affect Saudi female consumer acceptance of mobile marketing.

Therefore this paper seeks to fill the gap in the mobile marketing literature from a female consumer's perspective. Furthermore, this paper will investigate mobile marketing acceptance factors and identify the most crucial factors to help marketers reach their consumers.

\section{Research Objectives}

- $\quad$ To address the current usage of mobile marketing by the Saudi female.

- To investigate Saudi female consumer mobile marketing acceptance.

- To explain how the most influential factors such as providing information, sharing content, accessing content, personal attachment, and perceived value. 


\section{Problem Statement}

The main purpose of this paper is to explore mobile marketing consumer acceptance factors. Accordingly, for more understanding in regards to consumer acceptance of mobile marketing, this paper will address mobile marketing and determine the most influential factors from a consumer's perspective.

\section{Importance of the Study}

This study contributes to increase the understanding of the important factors that affect mobile marketing acceptance. Hence, this study considered the first attempts to identify factors that affect mobile marketing acceptance in Saudi Arabia. This study also contributes to the growing literature on mobile marketing by investigating the acceptance of Saudi female consumers of mobile marketing. Finally this study will provide empirical evidence of mobile acceptance factors among the Saudi context.

This paper proceeds as follows: in the next section, a literature review on the study variables will be presented followed by conceptual background and hypotheses, a description of the method used, data collection method, sampling framework, and measurement description will be addressed. Finally, data analysis and study results followed by a conclusion and study limitation will be provided.

\section{Literature Review}

\subsection{Mobile Marketing Acceptance}

Mobile technologies are crucial in today's businesses (Haghirian et al., 2005). They provid emany opportunities for marketing activities and communications than does traditional media (Friedrich et al., 2009; Haghirian et al., 2008).

Many scholars have pointed out the importance of mobile technology as a strategic issue. Mobile technology integrates the Internet and computers into wireless environment communication. Furthermore, the improvement in mobile technology devices opens the door to surf the Internet, find locations with GPS, watch movies, play games, and so on (Balasubramanian et al., 2002; Siau et al., 2005). Therefore, as consumers are increasingly exposed to mobile marketing, their acceptance is also increasing. Deng et al. (2010) define mobile marketing acceptance as "an individual consumer's propensity to accept new technologies and use them in a way that they will find useful". Some scholars define mobile marketing as the use of mobile to personal information, provide others with specific locations, one-to-one communication, and for entertainment (Bauer, 2005; Gao et al., 2010).

According to the factors that influence consumer acceptance of mobile marketing, studies show that different factors have been addressed (Barnes \& Scornavacca, 2004; Barwise \& Strong, 2002; Bauer et al., 2005; Carroll et al., 2007; Kavassalis et al., 2003; Leppa"niemi \& Karjaluoto, 2005; Siau et al., 2005). The finding of these studies pointed out factors such as providing information, trust, control over the transaction, perceived value, consider risk, etc. Smutkuptet et al. (2012) pointed out that there is a high correlation between consumer skills and sense of control related to Internet use and online shopping and accessing product information.

\subsection{Providing Information}

Most mobile marketing use is concerned with providing information to either send or receive (Kim, 2002). Mobile marketing's first goal is to present information to the final user. Furthermore, different information is available using phone devices. The majority of consumers are seeking direct communication to receive information (Stewart \& Pavlou, 2002).The network allows people, marketers, and organizations to send and receive relevant information by providing demographic, geographic, and subscriber information.

\subsection{Sharing Content}

Consumers are mostly involved in mobile marketing to share text content. Thus the content needs to be relevant and directly accepted by consumers (Roach, 2009). Digital channel content acceptance was perceived as disturbing by high-involvement consumers and perceived positively by those who are low involvement (Sultan et al., 2009).

\subsection{Accessing Content}

Using mobile marketing opens the door for people to access abundant content. Mobile marketing allows people to access more content than do traditional and email channels. Studies find that information privacy content obtained by mobile users is a concern that can be mitigated by other factors (Kavassalis et al., 2003). The probability of accessing different content relies heavily on expectations, experience, and mobile devices.

\subsection{Personal Attachments}

Personal attachment is one of the important constructs that represent the self through personalized features (Peng 
\& Spencer, 2006).These self features include ringtones, wallpapers, special content, etc. Studies that examine personal attachment are rare (Kim, 2002).

\subsection{Perceived Value}

Cronin et al. (2000) pointed out that perceived value is a "trade-off between what customers receive, such as quality, benefits, and utilities, and what they sacrifice, such as price, opportunity cost, time, and efforts." Persaud \& Azhar (2012) stated that perceived value is the consumer's overall assessment of the benefits of a product. Thus the perceived value of mobile marketing is the personal information in the shopping context. Another definition of perceived value by Kim et al. (2007): "It is the consumer's overall assessment of the utility of a product based on perceptions of what is received and what is given."

\section{Research Hypotheses}

H1: Providing information is positively related to mobile marketing acceptance.

$\mathrm{H} 2$ : Sharing content is positively related to mobile marketing acceptance.

H3: Accessing content is positively related to mobile marketing acceptance.

H4: Personal attachment is positively related to mobile marketing acceptance.

H5: Perceived value is positively related to mobile marketing acceptance.

\section{Research framework}

\subsection{Research Conceptual Model}

This study will be based on the following developed model:

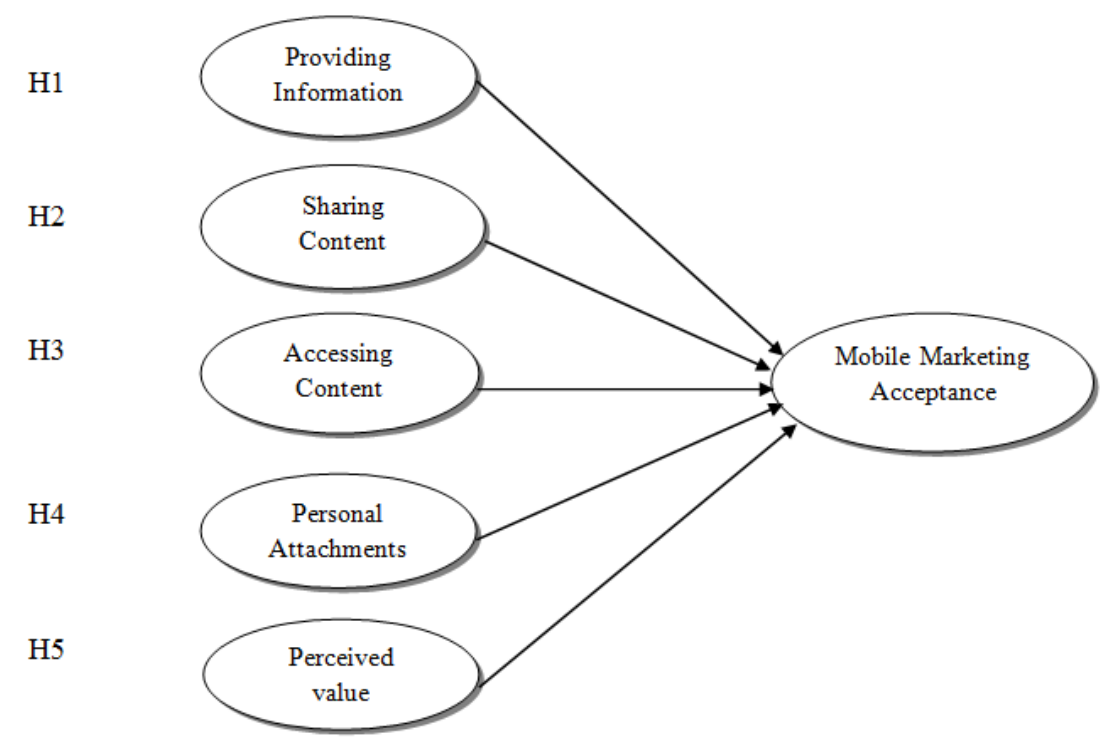

Figure 1. Research model

\section{Research Methodology}

\subsection{Data Collection Method and Sampling Framework}

The present study aims to examine in a quantitative method the mobile marketing acceptance factors from a customer's point of view. Thus the population involved all Saudi female consumers using mobile marketing. Accordingly, a probability sampling technique was used to administer a consumer survey; a random simple sample method was adopted to collect the data. The sample contains all female consumers from different ages and different positions in Riyadh. Participants were informed of the purpose of the research, and they were informed their responses would remain confidential. The proposed number for the sample is 300 participants. The retrieved questionnaires were 257 ( 31 were excluded because of incompletion). Thereforethe valid questionnaires to the statistical analysis were 226 , with a $75 \%$ response rate. 


\subsection{Instrument Design}

The scales used in this study have been sourced from literature. Five scales for this study were adopted from Sultan et al. (2009): providing information, sharing content, accessing content, personal attachment, and mobile marketing acceptance. Perceived value scale items were adopted from Sultan et al. (2012). Demographic variables were added in a separate part of the questionnaire. The survey items for the scales are listed in the appendix.

The questionnaire was initially developed in English then translated into Arabic. To ensure translation equivalence, the questionnaire was then back-translated into English. Face validity was done by marketing academic professors; this helped to clarify ambiguous questions. The coefficient alpha is 0.85 , which reflects good internal consistency of the scales.

\subsection{Analysis Technique}

The collected data was analyzed by using SPSS; frequency and percentages were calculated to interpret the demographic characteristic of the students. As the sample size was large (226 cases), regression analysis was adopted to identify the most important contributing variables used in the current study. Regression analysis assumes that variables have normal distributions and linearity of the relationship between the dependent and the independent variables in the model. This technique was used to measure the different levels of association between study variables.

\section{Results}

Regression analysis was used to explore the association between the independent variables and mobile marketing acceptance. The model summary shows good sampling adequacy with 0.805 . Providing information hypothesis $\mathrm{H} 1$ is supported; the results support $\mathrm{H} 1$ as a prediction of significant providing information with mobile marketing acceptance (p.0.004<0.05). The coefficient $\beta=0.198$ indicates positive association between providing information and mobile marketing acceptance. On the other hand, sharing content $\mathrm{H} 2$ is significant with (p0.000 $<0.05$ ) the coefficient $\beta=0.282$, which means positive association between sharing content and mobile marketing acceptance. The third hypothesis H3 is supported with (p $0.000<0.05)$, and $\beta=0.290$ meansthere is positive association between accessing content and mobile marketing acceptance. Personal attachment H4 (p.000 $<0.05$ ), the coefficient $\beta=0.388$ indicates good association between personal attachment and mobile marketing acceptance. Finally, H5 perceived value is supported as (p $0.000<0.05)$, and positive association was found $\beta=$ 0.482 . Table 1 provides a summary of the analysis results.

Table 1. Analysis results

\begin{tabular}{llll}
\hline Hypotheses & $\boldsymbol{\beta}$ & P-value & Results \\
\hline Providing information & 0.198 & 0.004 & Supported \\
Sharing content & 0.282 & 0.000 & Supported \\
Accessing content & 0.290 & 0.000 & Supported \\
Personal attachment & 0.388 & 0.000 & Supported \\
Perceived value & 0.482 & 0.000 & Supported \\
\hline
\end{tabular}

\section{Discussion and Conclusion}

This research attempts to investigate the influential factors of mobile marketing among Saudi females. The paper studies the influences of providing information, sharing content, accessing content, personal information, and perceived value. Testing the acceptance of mobile marketing indicates a significant effect of the study variables among females as a marketing tool. Saudi women believe that their culture's changes and technological advancements have a positive impact on their lifestyles (Bauer et al., 2005; Tao et al., 2010).

Therefore this study adds greater depth on Saudi female choices and how marketing changes affect their decisions. Furthermore, the study adds to the literature by examining Saudi female consumers as a large and growing market (Roach et al., 2009; Smutkupt et al., 2012).

\section{Limitation and Future Studies}

This research has examined consumer acceptance of mobile marketing in the Saudi context; the study was conducted in Riyadh where the consumers are more mature than in other regions. The study focuses on some 
factors that are more influential according to previous studies. Therefore it is recommended that future research extend this study in other cities and regions for generalization issues. Further research needs to explore consumer social financial factors as well. It is also interesting to examine the effect of the demographic variables on mobile marketing acceptance.

\section{References}

Balasubramanian, S., Peterson, R. A., \& Jarvenpaa, S. L. (2002). Exploring the implications of m-commerce for markets and marketing. Journal of the Academy of Marketing Science, 30(4). http://dx.doi.org/10.1177/009207002236910

Bauer, H., Reichardt, S. J., \& Neumann, M. (2005). Driving consumer acceptance of mobile marketing. Journal of Electronic Commerce Research, 6(3), 181-192.

Cronin, J., Brady, M. K., \& Hult, G. T. (2000). Assessing the effects of quality, value, and customer satisfaction on consumer behavioral intentions in service environment. Journal of Retailing, 76(2), 193-218. http://dx.doi.org/10.1016/S0022-4359(00)00028-2

Deng, Z., Lu, Y., \& Chen, Z. (2010). Exploring Chinese User Adoption of Mobile Banking. International Journal of Information Technology and Management, 9(3), 289-301. http://dx.doi.org/10.1504/IJITM.2010.030945

Friedrich, R., Gröne, F., Hölbling, K., \& Peterson, M. (2009). The march of mobile marketing: New chances for consumer companies, new opportunities for mobile operators. Journal of the Advertising Research. http://dx.doi.org/10.2501/S0021849909090096

Gong, W., \& Li, Z. G. (2008). Mobile youth in China: Acultural perspective and marketing implications. International Journal of Electronic Business, 6(3), 261-81. http://dx.doi.org/10.1504/IJEB.2008.019107

Haghirian, P., Madlberger, M., \& Inoue, A. (2008). Mobile advertising in different stages of development: Across-country comparison of consumer attitudes. 41st Hawaii International Conference on System Sciences.

Haghirian, P., Madlberger, M., \& Tanuskova, A. (2005). Increasing Advertising Value of Mobile Marketing-An Empirical Study of Antecedents. 38th Hawaii International Conference on System Sciences. http://dx.doi.org/10.1109/HICSS.2005.311

Kavassalis, P., Spyropoulou, N., Drossos, D., Mitrokostas, E., Gikas, G., \& Hatzistamatiou, A. (2003). Mobile permission marketing: Framing the market inquiry. International Journal of Electronic Commerce, 8(1), $55-79$.

Kim, H.-W., Chan, H. C., \& Gupta, S. (2007). Value-based adoption of mobile Internet: An empirical investigation. Decision Support Systems, 43, 111-26. http://dx.doi.org/10.1016/j.dss.2005.05.009

Kim, S. D. (2002). Perceptual Contact: Mobile Communication, Private Talk, Public Performance. Cambridge: University Press, Cambridge.

Peng, B., \& Spencer, I. (2006). Mobile marketing: The Chinese perspective. International Journal of Mobile Marketing, 1(2), 50-9.

Persaud, A., \& Azhar, I. (2012). Innovative mobile marketing via smartphone: Are consumers ready? Marketing Intelligence \& Planning, 30(4), 418-443. http://dx.doi.org/10.1108/02634501211231883

Plant, S. (2006). On the mobile: the effects of mobile telephones on social and individual life. Retrieved October 20, 2006, from www.motorola.com/mot/dod/0/234_MotDoc.pdf

Roach, G. (2009). Consumer perceptions of mobile phone marketing: A direct marketing innovation. Direct Marketing: an International Journal, 3(2), 124-138. http://dx.doi.org/10.1108/17505930910964786

Sangwan, S., \& Pau, L. (2005). Diffusion of mobile terminals in China. European Management Journal, 23(6), 674-81. http://dx.doi.org/10.1016/j.emj.2005.10.012

Siau K., Hong, S., \& Fiona, F. (2005). Strategic implications of mobile technology: A case study using value-focused thinking. Journal of Strategic Information Systems, 14, 269-290. http://dx.doi.org/10.1016/j.jsis.2005.07.004

Smutkupt, P., Krairit, D., \& Khang, D. B. (2012). Mobile marketing and consumer perceptions of brand equity. Asia Pacific Journal of Marketing and Logistics, 24(4), 539-560. http://dx.doi.org/10.1108/13555851211259016 
Stewart, D., \& Pavlou, P. (2002). From consumer response to active consumer: Measuring the effectiveness of interactive media. Journal of the Academy of Marketing Science, 30(4), 376-396. http://dx.doi.org/10.1177/009207002236912

Sultan, F., Gao, T., Rohm, A., \& Wang, J. (2012). Avalue and risk model of consumers' mobile marketing acceptance: An exploratory study. DMEF Marketing Research.

Sultan, F., Rohm, A. J., \& Gao, T. (2009). Factors influencing consumer acceptance of mobile marketing: Atwo-country study of youth markets. Journal of Interactive Marketing, 23(4), 308-20. http://dx.doi.org/10.1016/j.intmar.2009.07.003

Tao, G., Fareena, S., \& Andrew, J. R. (2010). Factors influencing Chinese youth consumers' acceptance of mobile marketing. Journal of Consumer Marketing, 27(7), 574-583. http://dx.doi.org/10.1108/07363761011086326

\section{Appendix}

\section{Questionnaire}

Please answer all the questions by circling the appropriate answer, where (1) means strongly disagree and (5) means strongly agree.

\begin{tabular}{|c|c|c|c|c|c|c|}
\hline NO. & The statements & $\begin{array}{l}\text { Strongly } \\
\text { disagree } \\
\text { (1) }\end{array}$ & (2) & (3) & (4) & $\begin{array}{l}\text { Strongly } \\
\text { agree } \\
\text { (5) }\end{array}$ \\
\hline
\end{tabular}

1. Providing Information

1.1 Provide your e-mail address to a website using your cell phone.

1.2 Register with a website using your cell phone.

1.3 Register for a contest or promotion using your cell phone.

\section{Sharing Content}

2.1 Friends often send me cool downloads such as ringtones or screen graphics on my cell phone.

2.2 I often send my friends new screen graphics or ringtones on their cell phones.

3. Accessing Content

3.1 Download content (wallpaper, ringtone, others) using your cell phone.

3.2 Access fun and entertaining content such as ringtones or games using your cell phone.

3.3 Pay for content such as games or ringtones for your cell phone.

4. Personal Attachments

4.1 I like to customize my cell phone with interesting screen graphics or wallpaper.

4.2 The way my cell phone looks and is designed is important to me.

4.3 I like to customize my cell phone with new ringtones.

5. Mobile Marketing Acceptance

5.1 I would be willing to receive information on where to buy certain products or services on my cell phone.

5.2 I would be willing to receive offers on my cell phone from companies selling products related to an event I am attending (for instance, a sporting event).

5.3 Overall, I would be willing to receive solicitations from companies to whom I gave my permission.

6. Perceived Perceived Value

6.1 Compared to withthe fee (e.g., application fee, registration fee) I need to pay, the use of mobile marketing offers value for money.

6.2 Compared to withthe effort (e.g., learn how to use) I need to put in, the use of mobile marketing is beneficial to me.

6.3 Compared to withthe time (e.g., searching time) I need to spend, the use of mobile marketing is worthwhile to me. 


\section{Personal Information}

Age:

$\square$ Less than 25
$\square 41-45$

$\square 25-30$
$\square \quad 46-50$

$\square$

31- 35

$36-40$

Education level:

$\square$ Secondary school

$\square$ Diploma degree

more than 50

$\square$ Master degree

Job Title:

$\square$ Administration

$\square$ Professor

$\square \mathrm{PhD}$ degree

$\square$ Bachelor degree

Monthly family income:

$\square$ Less than 5,000 SR

$\square 5,000-9,999$ SR

$10,000-14,999 \mathrm{SR}$

$\square 15,000-19,999 \mathrm{SR}$

\section{$\square$ Teacher \\ $\square$ Doctor}

$\square$ Lecturer

$\square$ Other

$\square$ More than 20,000 SR

*** Thank you for your participation $* * *$

\section{Copyrights}

Copyright for this article is retained by the author(s), with first publication rights granted to the journal.

This is an open-access article distributed under the terms and conditions of the Creative Commons Attribution license (http://creativecommons.org/licenses/by/3.0/). 